\title{
NEW FAUNISTICAL DATA ON ORIBATID MITES OF THE FAMILY DAMAEIDAE (ACARI, ORIBATIDA) FROM THE RUSSIAN FAR EAST
}

\author{
Nikolay A. Ryabinin ${ }^{1}$ and Sergey G. Ermilov ${ }^{*}$
}

\author{
${ }^{1}$ Institute of Water and Ecological Problems, Far Eastern Branch, Russian Academy of Sciences, \\ Khabarovsk, Russia \\ ${ }^{2} \mathrm{X}-\mathrm{BIO}$ Institute, Tyumen State University, Tyumen, Russia \\ *corresponding author; e-mail: ermilovacari@yandex.ru
}

\begin{abstract}
The present study is based on a random set of previously unstudied oribatid mites of the family Damaeidae, which were collected from the Russian Far East in 1987-2019. Based on the above material, we have identified 22 species and 12 genera from 28 localities. Of these, the genus Weigmannia and the species Epidamaeus craigheadi and Weigmannia parki have been recorded from the Palaearctic region for the first time. In addition, the genera Acanthobelba and Dyobelba, as well as the species Acanthobelba heterosetosa, Dyobelba biclavata, Damaeus maximus, D. striatus, and Epidamaeus variabilis, have been recorded from Russia (Far East) for the first time. The species Epidamaeus puritanicus has the highest occurrence across different biotopes.
\end{abstract}

KEY WORDS: Damaeid mites, fauna, list of taxa, new record, Russia.

DOI: 10.21684/0132-8077-2021-29-1-23-34

\section{INTRODUCTION}

The oribatid mite family Damaeidae (Acari, Oribatida) comprises 288 species and six subspecies (Subías, online version 2020) spread over 27 genera/ subgenera (opinions vary, e.g., Miko 2006; Ermilov and Norton 2014; Subías, online version 2020).

The family Damaeidae of the Russian Far East are moderately studied. Kulczynski (1926) was the first to mention damaeid mites on this territory; he described two new species (Oribata camtschaticus and $O$. bacillum) from Kamchatka. Later, Bulanova-Zachvatkina (1957a, b, 1962) described five more species (Belba paracorynopus, B. rossica, B. sellnicki, Epidamaeus grandjeani and E. microspinus). Subsequently, in her 1967 book, BulanovaZachvatkina listed 12 species and 6 genera of damaeids in the Russian Far East.

The 1960s marked the beginning of a systematic study of the Damaeidae in the Russian Far East. As a result, data on the fauna, taxonomy, distribution and other ecological aspects of damaeids from different regions of the Far East became available (e.g., Golosova 1969, 1971, 1981, 1987, 1989; Golosova and Krivolutsky 1976; Golosova and Pankov 1972, 1982; Kurcheva 1977; Lyashchev 1981, 1982, 1983, 1984; Makartseva 1970; Molodova 1970; Molodova and Golosova 1972; Bulanova-Zachvatkina 1975; Golosova et al. 1983; Krivolutsky et al. 1995). Pankov et al. (1997), Ryabinin and Pankov (2002), Ryabinin (2015) and Ryabinin et al. (2018) have published generalizing works (catalogues) on oribatid mites of the Russian Far East, including Damaeidae. As a result of these works, 31 damaeid species belonging to 10 genera were known in the Russian Far East prior to our study.

In the course of our taxonomic identification of a random set of previously unstudied oribatid mites from the Russian Far East-namely, from the Khabarovsk Territory, the Primorsky Territory, the Jewish Autonomous Region and the Sakhalin Region - we have found several representatives of the Damaeidae. The main goals of our paper are as follows: to provide a list of the identified taxa; to briefly note on the new records and findings; and to present SEM micrographs of some of the species that will help in their identification in the future.

\section{MATERIALS AND METHODS}

Specimens. Substrate samples containing oribatid mites were collected from the Russian Far East in 1987-2019 (Fig. 1). Mites were extracted into $70 \%$ ethanol using Berlese's funnels (without electric lamps) in laboratory conditions in the course of seven-eight days. After the study was complete, all the identified specimens have been deposited (in ethanol with a drop of glycerol) at the Tyumen State University Museum of Zoology, Tyumen, Russia. Substrate samples were collected from 28 localities:

1. Khabarovsk Territory, Bureinsky Reserve, Dusse-Alin Ridge, rocky summit, 1,507 m a.s.1., soil litter from a biotope with reindeer moss and Pinus pumila vegetation, $52^{\circ} 10^{\prime} 54^{\prime \prime} \mathrm{N}$, 134'26'23"E, 27.06.2016 (K. N. Tkachenko). 


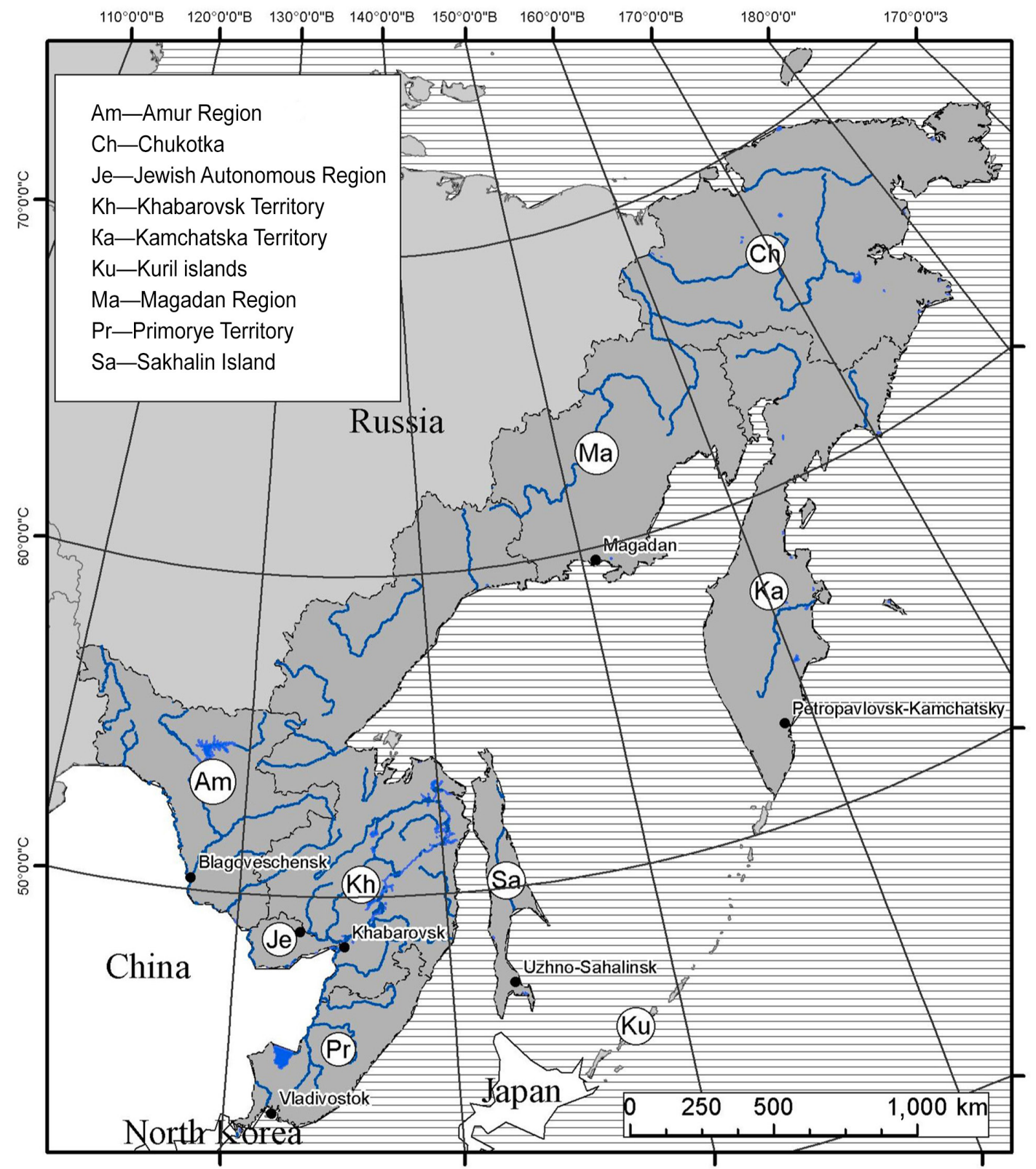

Fig. 1. Map of the Russian Far East.

2. Khabarovsk Territory, Bureinsky Reserve; $3 \mathrm{~km}$ from the mouth of the Umalta-Makit River, mountain spruce forest, western slope of a bluff, $650 \mathrm{~m}$ a.s.1., soil litter from a biotope with moss, Picea ajanensis, Pinus pumila, Larix sp. and Vaccinium vitis-idaea vegetation, $51^{\circ} 39^{\prime} 55^{\prime \prime} \mathrm{N}, 134^{\circ} 14^{\prime} 52^{\prime \prime} \mathrm{E}, 25.05 .2013$ (A. L. Antonov).

3. Khabarovsk Territory, Bureinsky Reserve, DusseAlin Ridge, near the headwaters of the Pravaya Bureya River, 1,611 m a.s.1., soil litter from a biotope with moss, lichen, Cassiope sp., Rhodiola rosea and Pinus pumila vegetation, $52^{\circ} 26^{\prime} 15^{\prime \prime} \mathrm{N}$, $134^{\circ} 26^{\prime 2} 23^{\prime \prime}$, 30.06.2011 (E.S. Koshkin).
4. Khabarovsk Territory, Bureinsky Reserve, ranger station "Strelka" $(3.5 \mathrm{~km}$ below the confluence of the Levaya Bureya and the Pravaya Bureya rivers), damp moss in a Picea ajanensis, Abies nephrolepis and Populus sp. forest, $51^{\circ} 38^{\prime} 15^{\prime \prime} \mathrm{N}, 134^{\circ} 15^{\prime} 17^{\prime \prime} \mathrm{E}, 23.05 .2016$ (E.S. Koshkin).

5. Khabarovsk Territory, Bureinsky Reserve, ranger station "Strelka", Pravya Bureya River, soil litter from an occasional floodplain, $51^{\circ} 38^{\prime} 22^{\prime \prime} \mathrm{N}, 134^{\circ} 16^{\prime} 05^{\prime \prime} \mathrm{E}, 22.06 .2018$ (A.L. Antonov).

6. Khabarovsk Territory, Bureinsky Reserve, boundary between the bottom of a rocky sum- 
mit and tundra, 1,481 $\mathrm{m}$ a.s.1., soil litter from a biotope with moss and lichen vegetation, $52^{\circ} 10^{\prime} 44^{\prime \prime} \mathrm{N}, 134^{\circ} 26^{\prime} 25^{\prime \prime} \mathrm{E}, 09.07 .2019$ (E.S. Koshkin).

7. Khabarovsk Territory, Bureinsky Reserve, Kuryaigagna Mountain Pass, Vodopadny Stream, mountain tundra, soil litter from a biotope with lichen, Sorbaria sp., Cassiope sp. and Artemisia sp. vegetation, $52^{\circ} 26^{\prime} 5^{\prime \prime} \mathrm{N}$, $135^{\circ} 01^{\prime} 55^{\prime \prime} \mathrm{E}, 03.07 .2017$ (A. Yu. Oleinikov).

8. Khabarovsk Territory, Duplikansky Reserve, near the Duplikan River, soil from a sparse Alnus sp. and Betula sp. forest stand, $50^{\circ}$ $51^{\prime} 01^{\prime \prime} \mathrm{N}, 132^{\circ} 51^{\prime} 08^{\prime \prime} \mathrm{E}, 23.08 .2006$ (D.K. Kurenshchikov).

9. Khabarovsk Territory, Verkhnebureinsky District, Lake Big Suluk, mountain tundra, 1,300 m a.s.1., soil litter from a Pinus pumila woodland, $51^{\circ} 18^{\prime} 38^{\prime \prime} \mathrm{N}, 134^{\circ} 20^{\prime} 49^{\prime \prime} \mathrm{E}$, 09.09.2014 (A. Yu. Oleinikov).

10. Khabarovsk Territory, Ayano-Maisky District, village of Nelkan, soil litter from a dry pine forest with Rhododendron dauricum, Juniperus sp. and Sorbus sp., 57 $39^{\prime} 05^{\prime \prime} \mathrm{N}, 136^{\circ} 09^{\prime} 01^{\prime \prime} \mathrm{E}$, 29.08.2017 (A. Yu. Oleinikov).

11. Khabarovsk Territory, Ayano-Maisky District, near the village of Nelkan, soil litter from a Pinus pumila forest with Rhododendron dauricum and Vaccinium-vitis-idaea, 57 40 $14^{\prime \prime} \mathrm{N}$, $136^{\circ} 10^{\prime} 14^{\prime \prime}$ E, 03.07.2019 (A. Yu. Oleinikov).

12. Khabarovsk Territory, Ayano-Maisky District, village of Tsypanda, Malyi Uskup Spring, soil litter from a Pinus pumila forest with Rhododendron dauricum, $58^{\circ} 13^{\prime} 06^{\prime \prime} \mathrm{N}, 135^{\circ} 15^{\prime} 20^{\prime \prime} \mathrm{E}$, 03.07.2019 (A.Yu. Oleinikov).

13. Khabarovsk Territory, Dzhugdzhur Mountain Ridge, Serdok mountain pass, 1,200 m a.s.1., soil litter from a biotope with Pinus pumila and Alnus sp. vegetation, $55^{\circ} 40^{\prime} 09^{\prime \prime} \mathrm{N}, 134^{\circ} 25^{\prime} 49^{\prime \prime} \mathrm{E}$, 18.08.2010 (A. Yu. Oleinikov).

14. Khabarovsk Territory, Dzhugdzhur Mountain Ridge, Serdok mountain pass, 1,100 m a.s.1., soil-litter from a biotope with Pinus pumila, Vaccinium uliginosum and Alnus sp. vegetation, $55^{\circ} 39^{\prime} 48^{\prime \prime} \mathrm{N}, 134^{\circ} 25^{\prime} 20^{\prime \prime} \mathrm{E}, 18.08 .2010$ (A. Yu. Oleinikov).

15. Khabarovsk Territory, Urmi River drainage basin, the right bank of the Annushkin Stream, soil litter from a biotope with Pinus sp. and Larix sp. vegetation, $50^{\circ} 23^{\prime} 22^{\prime \prime} \mathrm{N}, 134^{\circ} 07^{\prime} 58^{\prime \prime} \mathrm{E}$, 21.06.2019 (A.L. Antonov).

16. Khabarovsk Territory, Ulchsky District, Amur River, moss on riverbank rocks, on the opposite side of Lake Khavanda, $61^{\circ} 20^{\prime} 41^{\prime \prime} \mathrm{N}, 138^{\circ} 52^{\prime}$ 44"E, 20.06.2006 (N. A. Ryabinin).

17. Khabarovsk Territory, Central Sikhote-Alin Mountains, source of the Gobilli River, lichenous mountain tundra, soil litter, $49^{\circ} 31^{\prime} 05^{\prime \prime} \mathrm{N}$, $138^{\circ} 44^{\prime 2} 26^{\prime \prime}$ E, 25.06.2014 (E.M. Klimina).

18. Khabarovsk Territory, Vaninsky District, Sichote-Alin Mountains, Chope Stream (tributary of the Tumnin River), $570 \mathrm{~m}$ a.s.1., moss from a forest biotope with Larix sp., Pinus pumila, Calamagrostis sp. and Bergenia pacifica vegetation, 49 $72^{\prime} 76^{\prime \prime} \mathrm{N}, 139^{\circ} 98^{\prime} 33^{\prime \prime} \mathrm{E}, 31.08 .2005$ (E. M. Klimina).

19. Khabarovsk Territory, Vaninsky District, $153^{\text {th }}$ $154^{\text {th }} \mathrm{km}$ of the Lidoga-Vanino Road, near the Gobilli River, soil in a riparian forest biotope with Salix sp., Populus sp. and Chosenia sp. vegetation, $49^{\circ} 17^{\prime} \mathrm{N}, 138^{\circ} 26^{\prime} \mathrm{E}, 16.09 .2006$ (D.K. Kurenshchikov).

20. Khabarovsk Territory, Bikinsky District, vicinities of the village of Lesopilnoe, soil litter from a biotope with Quercus mongolica and Acer ssp. vegetation, $40^{\circ} 44^{\prime} 00^{\prime \prime} \mathrm{N}, 134^{\circ} 19^{\prime} 20^{\prime \prime} \mathrm{E}$, 16.08.2008 (N.A. Ryabinin).

21. Jewish Autonomous Region, Bastak Reserve, Ivakin land type association, soil litter from a biotope with Quercus mongolica, Acer ssp. and broadleaved species, $48^{\circ} 59^{\prime} 24^{\prime \prime} \mathrm{N}, 133^{\circ} 02^{\prime} 58^{\prime \prime} \mathrm{E}$, 12.07.2009 (N. A. Ryabinin).

22. Primorsky Territory, Sovetsko-Gavansky District, middle course of the Botchi River, soil litter from a biotope with Picea sp. and Pinus koraiensis vegetation, $48^{\circ} 06^{\prime} 30^{\prime \prime} \mathrm{N}, 139^{\circ} 20^{\prime}$ 57"E, 21.07.2006 (A. Yu. Oleinikov).

23. Primorsky Territory, Ussuriysky District, the village of Gorno-Tayozhnoye $(25 \mathrm{~km}$ southeast of the city of Ussuriysk), soil in the oak forest near the Gornotayozhnaya research station (Russian Academy of Sciences) named after

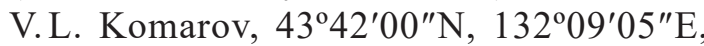
08.06.2006 (A. A. Baburin).

24. Primorsky Territory, Khasansky District, village of Barabash, "Land of Leopard" Reserve, litter from forest with Quercus mongolica, Acer spp. and Juglans mandshurica vegetation, $43^{\circ} 00^{\prime} 15^{\prime \prime} \mathrm{N}, 131^{\circ} 25^{\prime} 01^{\prime \prime} \mathrm{E}, 22.07 .2008$ (G.N. Ganin).

25. Sakhalin Region, Komandor Islands, Medny Island, Urilie-Glinki Mountain Pass, mountain tundra, soil litter from a biotope with Rhododendron dauricum and Empetrum sp. vegetation, 54 $21^{\prime} 11^{\prime \prime} \mathrm{N}, 167^{\circ} 33^{\prime} 51^{\prime \prime} \mathrm{E}, 14.08 .2011$ (A. Yu. Oleinikov). 
26. Sakhalin Region, Komandor Islands, Medny Island, the Big Waterfall, soil litter from blueberry thickets, $54^{\circ} 21^{\prime} 11^{\prime \prime} \mathrm{N}, 167^{\circ} 33^{\prime} 55^{\prime \prime} \mathrm{E}$, 18.08.2011 (A. Yu. Oleinikov).

27. Khabarovsky Territory, Badzhalsky Mountain Ridge, Mogda River, tundra, 1,000 m a.s.1., decaying moss near a spruce tree in a deciduous forest containing larch, spruce, alder, cedar elfin, ledum, cowberry and moss (Sphagnum sp.), 04.07.1987 (N. A. Ryabinin).

28. Primorsky Territory, Botchinsky Reserve, Baza Mountain, $400 \mathrm{~m}$ a.s. 1 , vicinities of the Mulpa River, soil from a forest containing cedar and spruce, $48^{\circ} 14^{\prime} 45^{\prime \prime} \mathrm{N}, 139^{\circ} 25^{\prime} 19^{\prime \prime} \mathrm{E}, 21.06 .2007$ (A. Yu. Oleinikov).

Observation and documentation. Specimens were mounted in lactic acid on temporary cavity slides for measurement and illustration. SEM micrographs were made with the aid of a JEOL-JSM6510LV SEM microscope.

Abbreviations. $A a, A p$-prodorsal tubercles; $P$-propodolateral apophysis; in - interlamellar seta; $b s$-bothridial seta; $b o$-bothridium; $B a-$ prodorsobasal tubercle; $c_{2}, l a, l m, l p$-notogastral setae; s. $a$.—spina adnata; $3 b, 3 c$ - epimeral setae; $\mathrm{Va}, \mathrm{Vp}$-ventrosejugal tubercles; $\mathrm{Sa}$ - parastigmatic tubercle.

\section{LIST OF IDENTIFIED TAXA}

Genus Acanthobelba Enami and Aoki, 1993

Acanthobelba heterosetosa Choi, 1997 (Fig. 2). Localities: 3, 18. Distribution: Korea.

Genus Belba Heyden, 1826

Belba rossica Bulanova-Zachvatkina, 1962. Localities: 5, 6, 19, 20, 21, 22, 23, 25. Distribution: Palaearctic region.

Genus Belbodamaeus Bulanova-Zachvatkina, 1967

Belbodamaeus gobilliensis Ermilov and Ryabinin, 2020. Localities: 5, 9, 20, 24, 25. Distribution: Russian Far East.

Genus Damaeus C.L. Koch, 1835

Damaeus maximus Mihelčič, 1957. Localities: 19, 24, 25. Distribution: central and southern Europe.

Damaeus striatus (Enami and Aoki, 1988) (Figs. 4-7). Localities: 19, 24, 25. Distribution: eastern Palaearctic region.

Genus Dyobelba Norton, 1979

Dyobelba biclavata Wang and Norton, 1993. Localities: 1, 3, 11, 12. Distribution: southeastern Palaearctic region. 1957

Genus Epidamaeus Bulanova-Zachvatkina,

Epidamaeus aborigensis Behan-Pelletier and Norton, 1985. Localities: 10, 11, 14, 24. Distribution: eastern Asian Russia.

Epidamaeus arcticolus (Hammer, 1952) (Figs. 8-13). Localities: 1, 3, 16, 17, 19, 20. Distribution: Boreal.

Epidamaeus chopeensis Ermilov and Ryabinin, 2020. Localities: 12, 14, 19, 24. Distribution: eastern Asian Russia.

Epidamaeus craigheadi (Jacot, 1939) (Figs. 14-16). Localities: 1, 5, 6, 10, 11, 19, 27. Distribution: USA (New Hampshire).

Epidamaeus fortispinosus Hammer, 1967. Localities: 15, 23. Distribution: Boreal.

Epidamaeus gilyarovi (Behan-Pelletier and Norton, 1985). Localities: 90, 97. Distribution: eastern Asian Russia.

Epidamaeus puritanicus (Banks, 1906) (Figs. 17, 18). Localities: 2, 3, 4, 6, 7, 10, 14, 16, 19, 20, 28. Distribution: Holarctic region.

Epidamaeus tritylos (Behan-Pelletier and Norton, 1983). Localities: 15, 26. Distribution: Boreal.

Epidamaeus variabilis Fujikawa and Fujita, 1985 (Figs. 19-22). Localities: 10, 17, 119, 21, 23, 24, 25. Distribution: Japan, northern China.

Genus Kunstidamaeus Miko, 2006

Kunstidamaeus bacillum (Kulczynski, 1926). Localities: 5, 6, 17, 26. Distribution: Russian Far East.

Kunstidamaeus ladislavmikoi Ermilov and Ryabinin, 2020 (Figs. 23-26). Localities: 1, 5, 6, 17, 21, 24, 25. Distribution: Russian Far East.

Genus Parabelbella Bulanova-Zachvatkina, 1967

Parabelbella rusfareastensis Ermilov and Ryabinin, 2020. Localities: 2, 28. Distribution: Russian Far East.

Genus Porobelba Grandjean, 1936

Porobelba spinosa (Sellnick, 1920) (Figs. 27, 28). Localities: 13, 19, 23. Distribution: Palaearctic region.

Genus Spatiodamaeus Bulanova-Zachvatkina, 1957

Spatiodamaeus ziemowiti Ermilov and Ryabinin, 2020. Localities: 23, 24. Distribution: Russian Far East.

Genus Tokukobelba Lamos, 2016

Tokukobelba compta (Kulczynski, 1902) (Figs. 29-32). Localities: 5, 16, 19, 20, 22, 23, 24. Distribution: Palaearctic region. 
Damaeidae from the Russian Far East
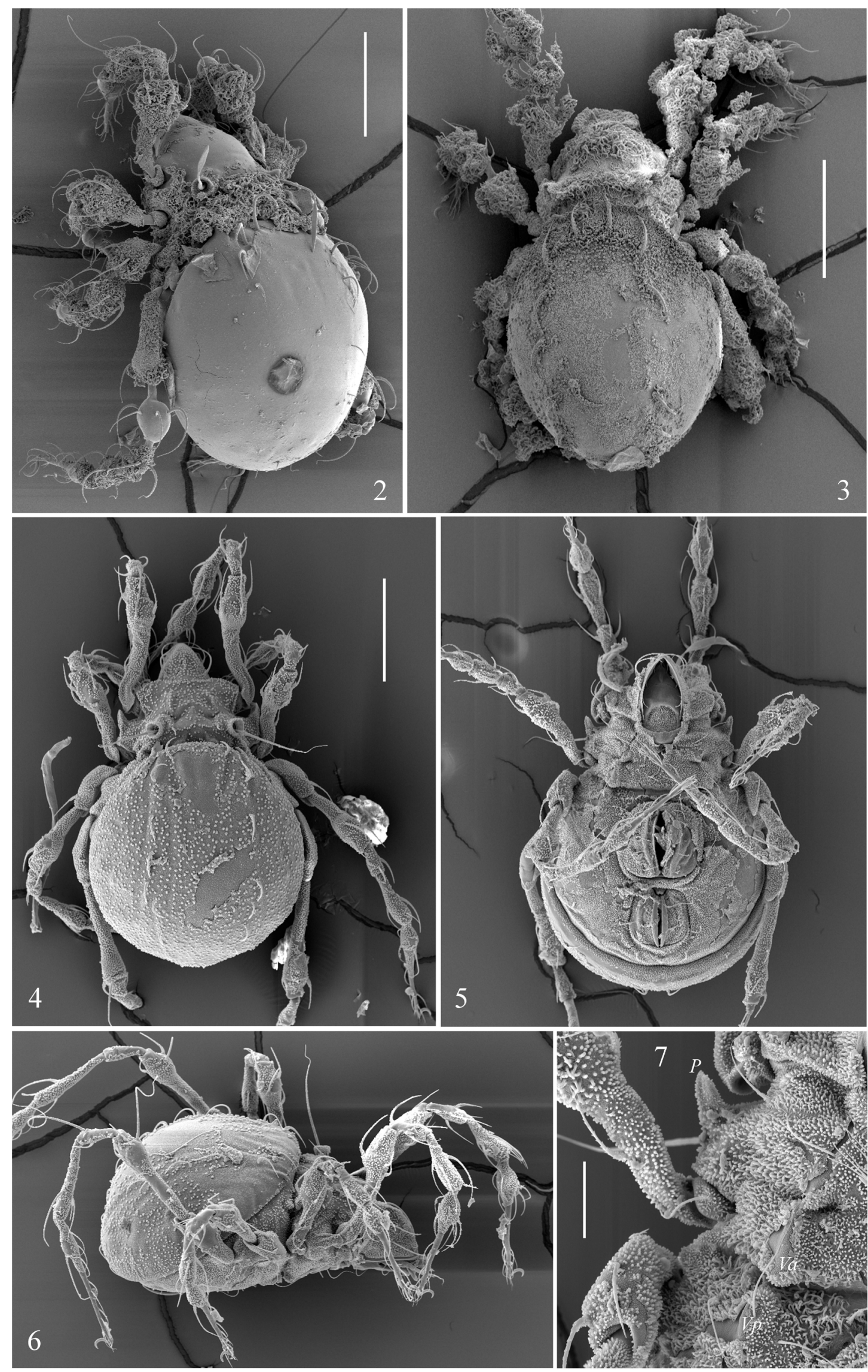

Figs. 2-7. SEM micrographs of Acanthobelba heterosetosa Choi, 1997 (2), Weigmannia parki (Jacot, 1937) (3) and Damaeus striatus (Enami and Aoki, 1988) (4-7). Scale bars $=200 \mu \mathrm{m}(4-6), 100 \mu \mathrm{m}(2,3), 50 \mu \mathrm{m}$ (7). 

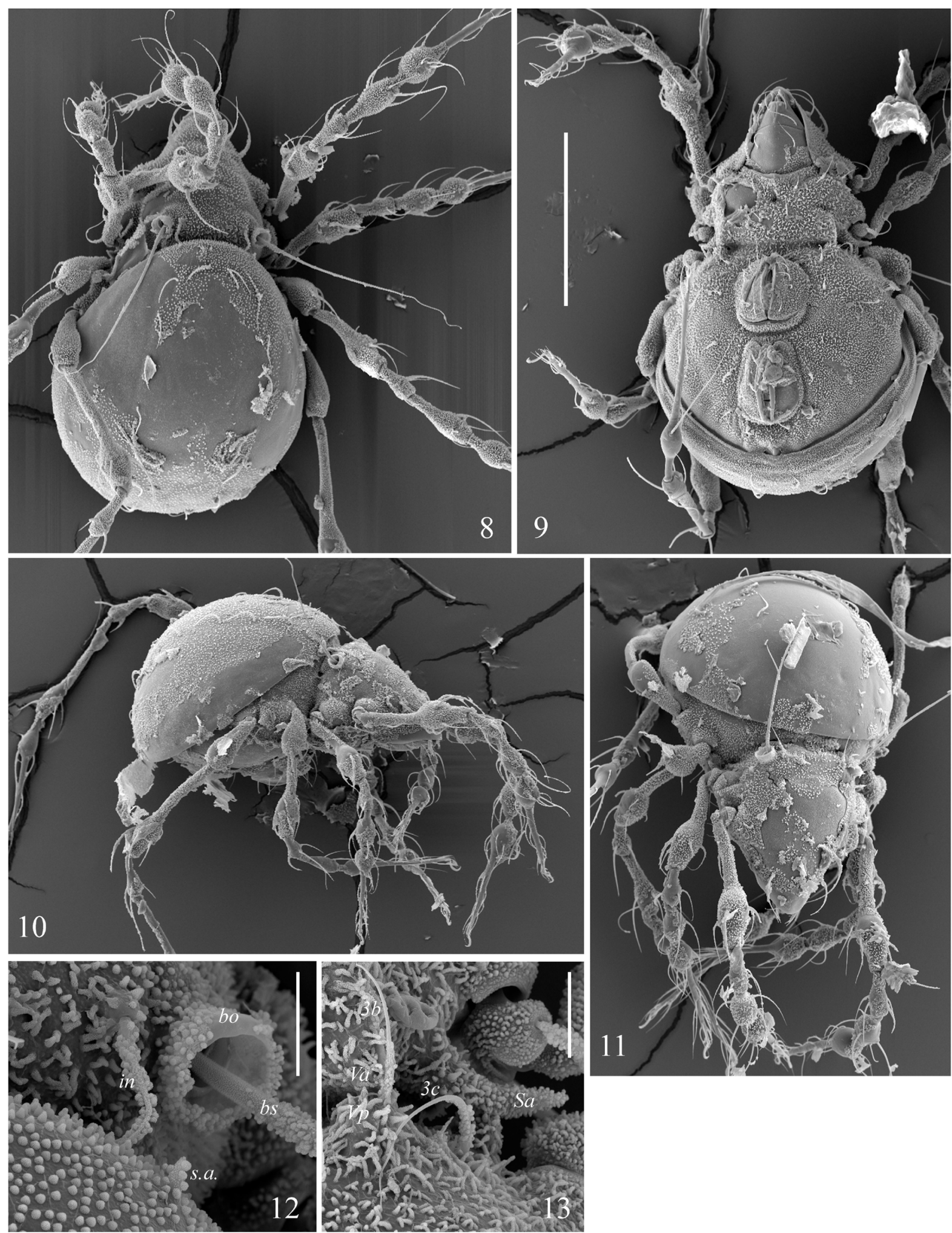

Figs. 8-13. SEM micrographs of Epidamaeus arcticolus (Hammer, 1952). Scale bars=200 $\mu \mathrm{m}(8-11), 20 \mu \mathrm{m}(12,13)$.

Genus Weigmannia Miko and Norton, 2010

Weigmannia parki (Jacot, 1937) (Fig. 3). Localities: 8, 19. Distribution: central and eastern Nearctic region, USA (Florida).
Remarks. The list of identified damaeid mites includes 22 species from 12 genera. Of these, five species (Belbodamaeus gobilliensis, Epidamaeus chopeensis, Kunstidamaeus ladislavmikoi, Parabelbella rusfareastensis and Spatiodamaeus ziemowiti) 

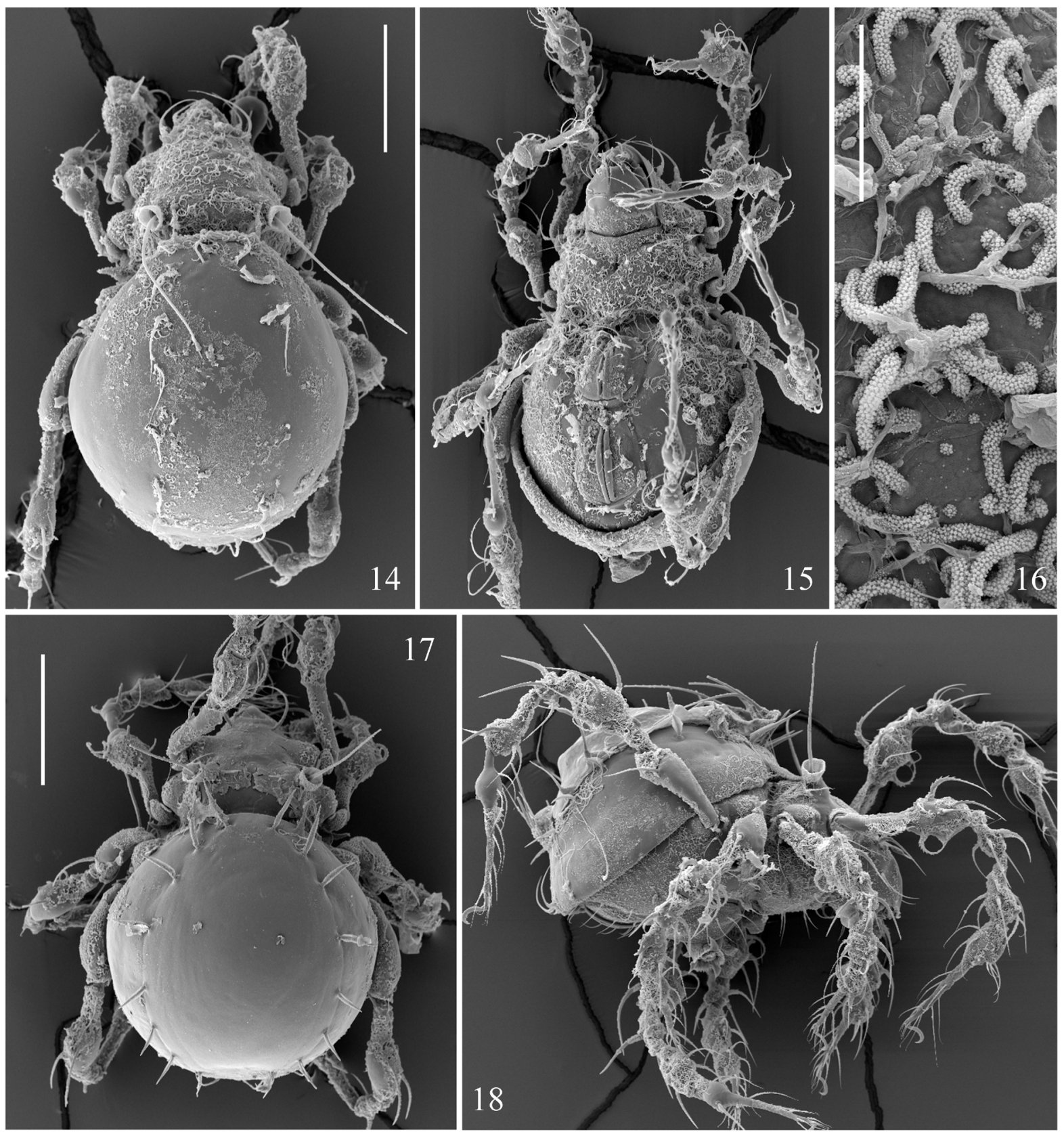

Figs. 14-18. SEM micrographs of Epidamaeus craigheadi (Jacot, 1939) (14-16) and Epidamaeus puritanicus (Banks, 1906) $(17,18)$. Scale bars $=200 \mu \mathrm{m}(17,18), 100 \mu \mathrm{m}(14,15), 10 \mu \mathrm{m}(16)$.

are new to science (Ermilov and Ryabinin 2020a-d); one genus (Weigmannia) and two species (Epidamaeus craigheadi and Weigmannia parki) have been recorded for the first time in the Palaearctic region; two genera (Acanthobelba and Dyobelba) and five species (Acanthobelba heterosetosa, Dyobelba biclavata, Damaeus maximus, D. striatus and Epidamaeus variabilis) have been recorded in Russia (Far East) for the first time. Species that are most frequently encountered in different biotopes are as follows: Epidamaeus puritanicus (encountered in 11 biotopes out of 28); Belba rossica (encountered in 8 biotopes); Epidamaeus craigheadi, E. variabilis, Kunstidamaeus ladislavmikoi and Tokukobelba compta (encountered in 7 biotopes).

Our data, as well as the previously published works (e.g., Ryabinin 2015; Ryabinin et al. 2018), suggest that the oribatid fauna of the family Damaeidae recorded in the Russian Far East now includes 44 species from 13 genera.

\section{ACKNOWLEDGEMENTS}

We thank the employees of the Institute of Water and Ecological Problems, Far Eastern 


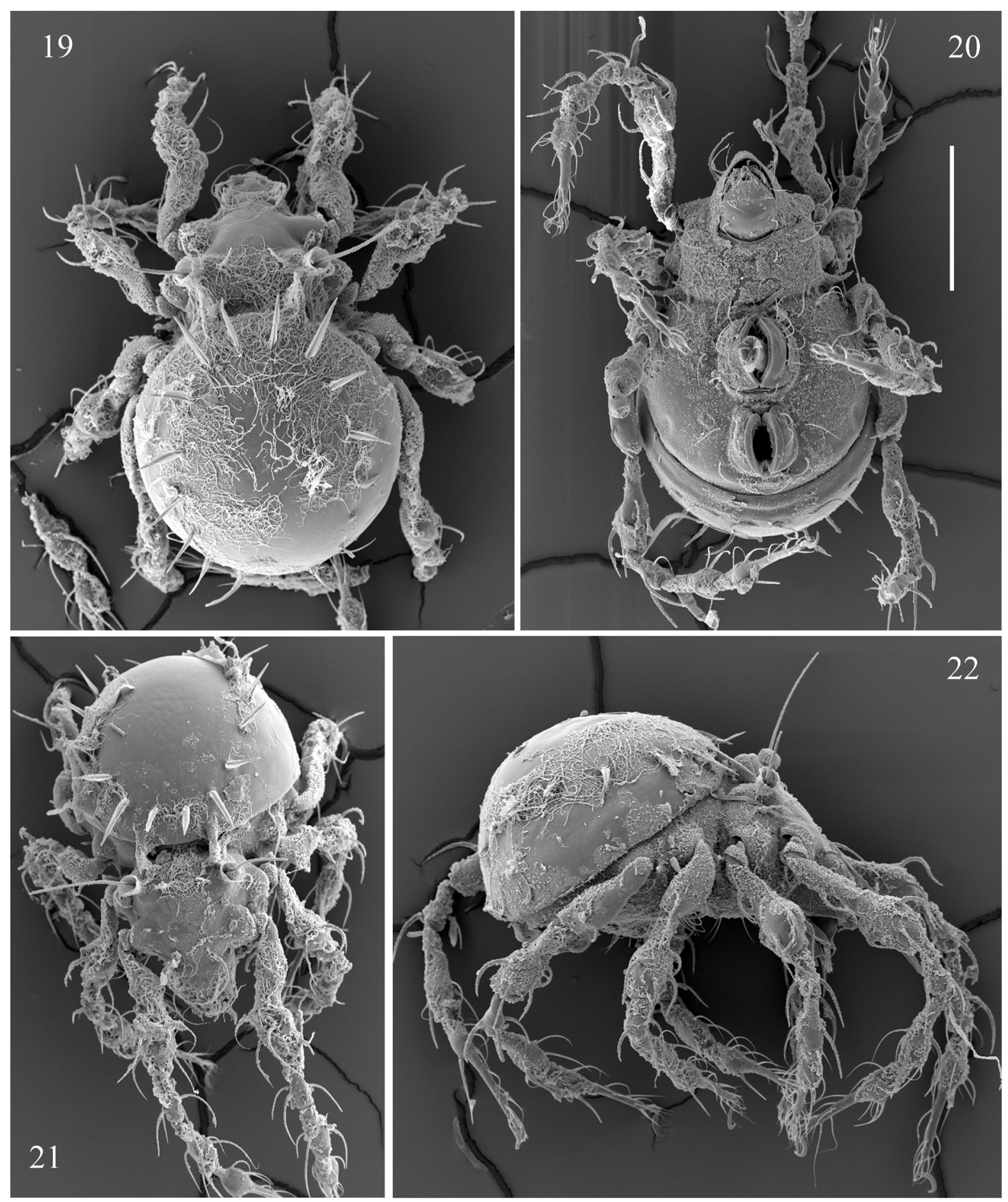

Figs. 19-22. SEM micrographs of Epidamaeus variabilis Fujikawa et Fujita, 1985. Scale bar=200 $\mu \mathrm{m}$.

Branch, Russian Academy of Sciences, Khabarovsk, Russia for their sampling assistance; and Alexey A. Gubin (Tyumen State University, Tyumen, Russia) for the SEM micrographs. The study was funded by the Russian Foundation for Basic Research (RFBR) (project № 18-04-00097) and by the RFBR and the Ministry of Education, Culture, Science and Sports (MECSS) (project № 2054-44014).

\section{REFERENCES}

Bulanova-Zachvatkina, E.M. 1957a. Epidamaeus grandjeani g. et sp.n.-novyy predstavitel oribatid s Kurilskikh ostrovov [Epidamaeus grandjeani Bul.Zachv., gen. et sp.n.-a new oribatid mite from Kuril Islands (Acariformes, Oribatei)]. Entomologicheskoe Obozrenie, 36(2): 547-552. [In Russian] Bulanova-Zachvatkina, E.M. 1957b. Bulavonogie pantsirnye kleshchi sem. Damaeidae p. Epidam- 

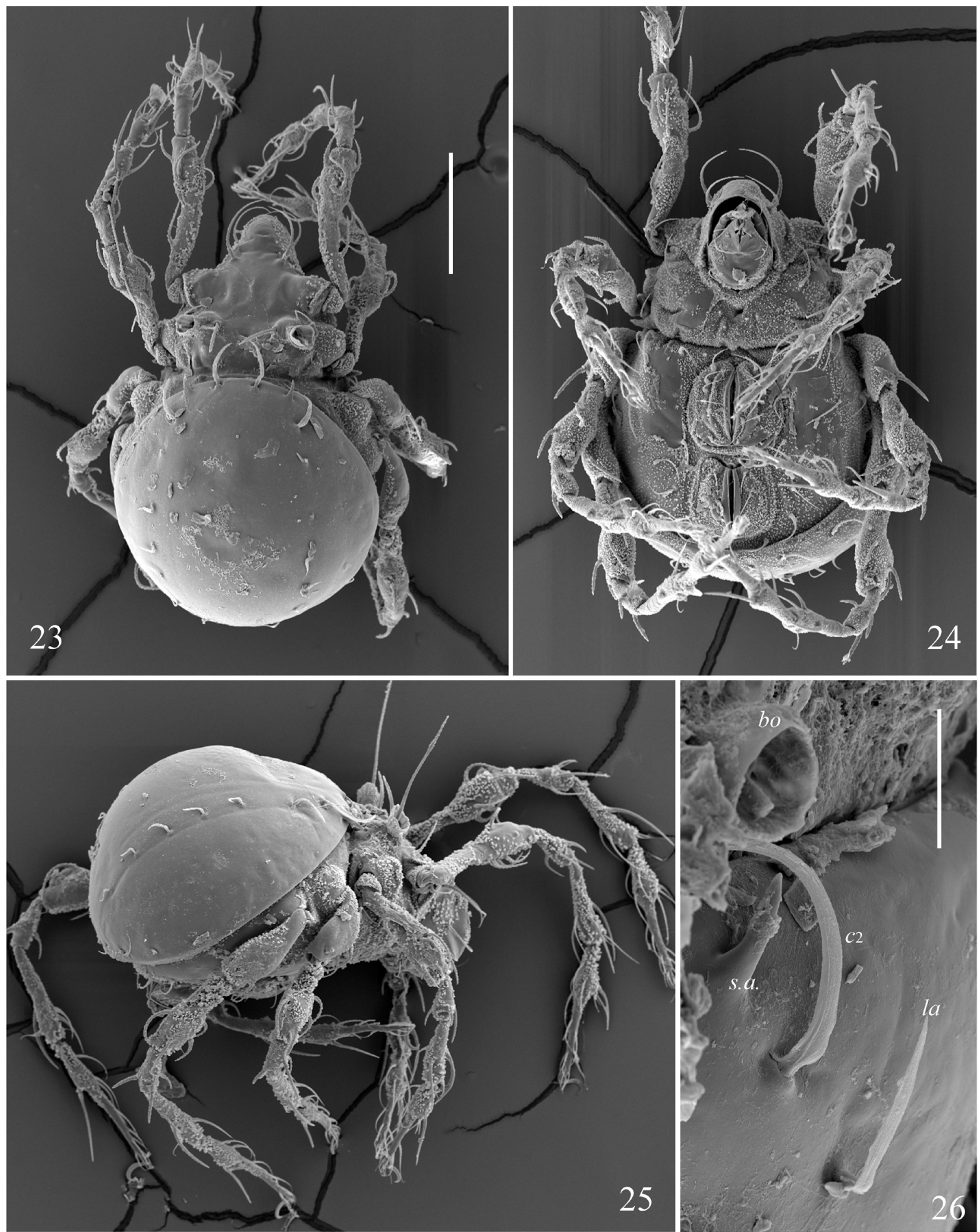

Figs. 23-26. SEM micrographs of Kunstidamaeus bacillum (Kulczynski, 1926). Scale bars=200 $\mu \mathrm{m}$ (23-25), $50 \mu \mathrm{m}$ (26).

aeus gen.nov. Soobshchenie II [Oribatid mites of Damaeidae Berl. Genus Epidamaeus gen.n. (Acariformes, Oribatei)]. Zoologichesky Zhurnal, 36(12): 1792-1801. [In Russian]

Bulanova-Zachvatkina, E.M. 1962. Bulavonogie pantsirnye kleshchi sem. Damaeidae Berl., 1896 (trib. Belbini, tr.nov.) [Oribatid mites of the family
Damaeidae Berlese, 1896 (Tribe Belbini, triba nov.)]. Zoologichesky Zhurnal, 41(2): 203-216.

Bulanova-Zachvatkina, E.M. 1967. Pantsirnye kleshchi-oribatidy [Oribatid Mites-Oribatida]. Higher School, Moscow. 254 pp. [In Russian]

Bulanova-Zachvatkina, E. M. 1975. Nadsemeystvo Belboidea [The superfamily Belboidea]. In: 

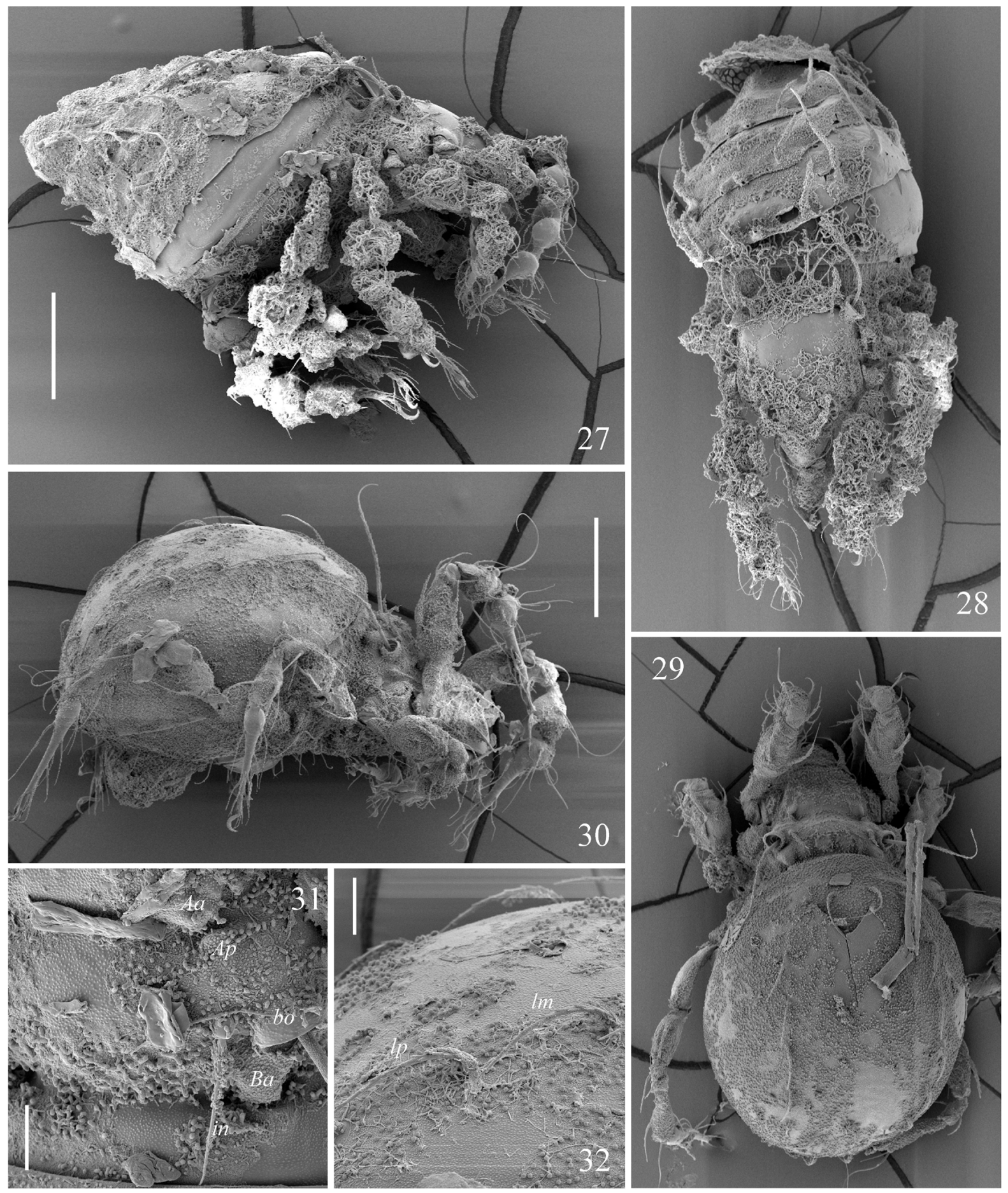

Figs. 27-32. SEM micrographs of Porobelba spinosa (Sellnick, 1920) $(27,28)$ and Tokukobelba compta (Kulczynski, 1902) (29-32). Scale bars $=100 \mu \mathrm{m}(27-30), 20 \mu \mathrm{m}(31,32)$.

M.S. Ghilyarov (Ed.). Opredelitel obitayushchikh v pochve kleshchey [Key to Soil Inhabiting Mites. Sarcoptiformes]. Nauka, Moscow, pp. 120-143. [In Russian]

Ermilov, S.G. and Ryabinin, N.A. 2020a. Contribution to the knowledge of Parabelbella (Acari, Oribatida, Damaeidae): description of two new species from Russia and the U.S.A., redescription of $P$. in- aequipes (Banks, 1947) and a key to known species. Zootaxa, 4860(3): 352-374.

Ermilov, S.G. and Ryabinin, N.A. 2020b. Kunstidamaeus ladislavmikoi sp. nov. (Acari: Oribatida: Damaeidae) from Russia, with supplementary description of Kunstidamaeus bacillum (Kulczynski, 1926) comb.nov. International Journal of Acarology, 46(5): 287-297. 
Ermilov, S. G. and Ryabinin, N.A. 2020c. New species of the genera Belbodamaeus and Epidamaeus (Acari, Oribatida, Damaeidae) from Russia. Systematic and Applied Acarology, 25(6): 1158-1168.

Ermilov, S.G. and Ryabinin, N.A. 2020d. Spatiodamaeus ziemowiti sp.nov. (Acari: Oribatida: Damaeidae) from Russia. Annales Zoologici, 70(3): 311-316.

Golosova, L.D. 1969. Fauna oribatid (Acariformes, Oribatei) poymennykh lesov yuzhnoy chasti Primorskogo kraya [Fauna of oribatids (Acariformes, Oribatei) of flood forests of the southern Primorsky Krai]. Zoologichesky Zhurnal, 48(9): 1337-1341. [In Russian]

Golosova, L. D. 1971. Pantsirnye kleshchi (Acariformes, Oribatei) khvoyno-shirokolistvennykh lesov yuzhnogo Primorya [Oribatid mites (Acariformes, Oribatei) of broad-leaved-coniferous forests of the southern Primorye]. In: Ecology of Animals: Scientific Notes. Vol. 465. Moscow State Pedagogical Institute, Moscow, pp. 111-123. [In Russian]

Golosova, L.D. 1981. Pantsirnye kleshchi Yuzhnogo Sakhalina [Oribatid mites of southern Sakhalin]. In: Ekologiya zhivotnykh i faunistika [Ecology of Animals and Faunistics]. Tyumen State University, Tyumen, pp. 22-37. [In Russian]

Golosova, L.D. 1987. Pantsirnye kleshchi Sibiri i Dalnego Vostoka [Oribatid mites of the Siberia and Far East]. In: B. R. Striganova (Ed.). Pochvennaya fauna i pochvennoe plodorodie: Tr. 9-go Mezhdunar. kollokviuma po pochvennoy zoologii [Soil Fauna and Soil Productivity: Proceedings IX International Colloquium of Soil Zoology]. Nauka, Moscow, pp. 555-556. [In Russian]

Golosova, L.D. 1989. Pantsirnye kleshchi Severnogo Primorya [Oribatid mites of the northern Primorye]. In: N. A. Ryabinin (Ed.). Pochvennye bespozvonochnye yuga Dalnego Vostoka [Soil Invertebrates of the Southern Far East]. Khabarovsk, pp. 20-25. [In Russian]

Golosova, L.D., Karppinen, E. and Krivolutsky, D.A. 1983. List of oribatid mites (Acarina, Oribatei) of northern Palaearctic region. II. Siberia and Far East. Acta Entomologica Fennica, 43: 3-14.

Golosova, L.D. and Krivolutsky, D.A. 1976. Pantsirnye kleshchi v pochvakh Ussuriyskogo zapovednika (Primorskiy kray) [Oribatid mites in soils of the Ussuriysky Reserve (Primorsky Krai)]. Fauna i ekologiya zhivotnykh Tyumenskoy oblasti [Fauna and Ecology of Animals of Tyumen Region], 31: 3-18. [In Russian]

Golosova, L.D. and Pankov, A.N. 1978. Pantsirnye kleshchi Kurilskikh ostrovov [Oribatid mites of
Kuril Islands]. In: Ekologiya zhivotnykh i faunistika [Ecology of Animals and Faunistics]. Tyumen State University, Tyumen, pp. 3-18. [In Russian]

Golosova, L.D. and Pankov, A.N. 1982. Nekotorye dannye o pantsirnykh kleshchakh (Oribatei) Kamchatki [Some data on oribatid mites of Kamchatka]. In: Ekologiya zhivotnykh i faunistika [Ecology of Animals and Faunistics]. Tyumen State University, Tyumen, pp. 29-38. [In Russian]

Krivolutsky, D. A., Lebrun, P., Kunst, M., Akimov, I.A., Bayartogtokh, B., Vasiliu, N., Golosova, L.D., Grishina, L.G., Karppinen, E., Kramnoy, V.Ya., Laskova, L.M., Luxton, M., Marshall, V., Matveenko, A.A., Netuzhilin, I.A., Norton, R., Sitnikova, L.G., Smrž, J., Starý, J., Tarba, Z.M., Shaldybina, E.S., Eitminavichute, I. 1995. Pantsirnye kleshchi: morfologiya, razvitie, filogeniya, ekologiya, metody issledovaniya, kharakteristika modelnogo vida Nothrus palustris CL Koch [Oribatid Mites: Morphology, Development, Phylogeny, Ecology, Methods of Study and Characteristics of the Model Species Nothrus palustris]. Nauka, Moscow. 224 pp. [In Russian]

Kulczynski, V. 1926. Arachnoidea camtschadalica. Annuaire du Musée Zoologique de l'Académie des Sciences de l'URSS, 27: 29-72.

Kurcheva, G.F. 1977. Pochvennye bespozvonochnye sovetskogo Dalnego Vostoka [Soil Invertebrates of the Soviet Far East]. Nauka, Moscow. 132 pp. [In Russian]

Lyashchev, A.A. 1981. Pantsirnye kleshchi severnogo Sakhalina [Oribatid mites of northern Sakhalin]. In: Ekologiya zhivotnykh i faunistika [Ecology of Animals and Faunistics]. Tyumen State University, Tyumen, pp. 3-21. [In Russian]

Lyashchev, A.A. 1982. Oribatidy yugo-vostochnoy pribrezhnoy zony o. Sakhalin [Oribatid mites of coastal zone of southeast Sakhalin]. In: Ekologiya zhivotnykh i faunistika [Ecology of Animals and Faunistics]. Tyumen State University, Tyumen, pp. 7-16. [In Russian]

Lyashchev, A.A. 1983. Pantsirnye kleshchi zapadnogo poberezhya o. Sakhalin [Oribatid mites of coast of the western Sakhalin]. In: Ekologiya zhivotnykh i faunistika [Ecology of Animals and Faunistics]. Tyumen State University, Tyumen, pp. 24-37. [In Russian]

Lyashchev, A.A. 1984. Pantsirnye kleshchi o. Sakhalin [Oribatid mites of Sakhalin Island]. Abstract of the Candidate of Biological Sciences thesis. Leningrad. 22 pp. [In Russian]

Makartseva, E. P. 1970. Studies on the specific composition and densities of oribatid mites in the Nadezhdinsk District (Primorsky region)]. In: 
I. S. Eitminavičiūtè (Ed.). Oribatei and Their Role in the Process of the Soil Formation. Vilnius, pp. 131-136.

Miko, L. 2006. Damaeoidea Berlese, 1896. In: G. Weigmann (Ed.). Hornmilben (Oribatida). Die Tierwelt Deutschlands. Teil. 76. Goecke and Evers, Keltern, pp. 179-207.

Miko, L. and Norton, R.A. 2010. Weigmannia n. gen. from eastern North America, with redescription of the type species, Porobelba parki Jacot, 1937 (Acari, Oribatida, Damaeidae). Acarologia, 50(3): 343-356.

Molodova, L.P. 1970. On the oribatid mite fauna of the southern Sakhalin. In: I.S. Eitminavičiūtè (Ed.). Oribatei and Their Role in the Progress of the Soil Formation. Vilnius, pp. 81-84.

Molodova, L.P. and Golosova, L.D. 1972. The oribatid mites in vertical soil and vegetation zones in the southern part of Sakhalin. Pedobiologia, 12: 424-429.

Norton, R.A. and Ermilov, S.G. 2014. Catalogue and historical overview of juvenile instars of oribatid mites (Acari: Oribatida). Zootaxa, 3833(1): 1-132.

Pankov, A.N., Ryabinin, N.A. and Golosova, L.D. 1997. Katalog pantsirnykh kleshchey Dalnego
Vostoka Rossii. Chast I. Katalog pantsirnykh kleshchey Kamchatki, Sakhalina i Kurilskikh ostrovov [Catalogue of Oribatid Mites of the Russian Far East. Part I. Catalogue of Oribatid Mites of Kamchatka, Sakhalin and Kuril Islands]. Dalnauka, Vladivostok-Khabarovsk. 87 pp. [In Russian]

Ryabinin, N. A. 2015. Oribatid mites (Acari, Oribatida) in soils of the Russian Far East. Zootaxa, 3914(3): 201-244.

Ryabinin, N.A. and Pankov, A.N. 2002. Katalog pantsirnykh kleshchey Dalnego Vostoka Rossii. Chast II. Kontinentalnaya chast Dalnego Vostoka [Catalogue of Oribatid Mites of the Russian Far East. Part II. Continental Part of the Far East]. FEB RAS, Vladivostok-Khabarovsk. 92 pp. [In Russian]

Ryabinin, N.A., Liu, D. Gao, M. and Wu, D.-H. 2018. Checklist of oribatid mites (Acari, Oribatida) of the Russian Far East and Northeast of China. Zootaxa, 4472(2): 201-232.

Subías, L.S. 2020. Listado Sistemático, Sinonímico y Biogeográfico de los Ácaros Oribátidos (Acariformes: Oribatida) del Mundo (Excepto Fósiles). $15^{\mathrm{a}}$ actualización. $527 \mathrm{pp}$. 